\title{
Cytotoxic T Cell Response Against the Chimeric p210 BCR-ABL Protein in Patients with Chronic Myelogenous Leukemia
}

\author{
Patricia Yotnda, ${ }^{*}$ Hüseyin Firat, ${ }^{*}$ François Garcia-Pons, ${ }^{\star}$ Zacarias Garcia, ${ }^{\star}$ Géraldine Gourru, ${ }^{\S}$ Jean-Paul Vernant, ${ }^{\ddagger}$ \\ François A. Lemonnier, ${ }^{\star}$ Véronique Leblond, ${ }^{\ddagger}$ and Pierre Langlade-Demoyen ${ }^{\star}$ \\ *Unité d'Immunité Cellulaire Antivirale, Institut Pasteur, 75724 Paris, Cédex 15, France; ${ }^{\ddagger}$ Département d'Hématologie, CNRS URA 625 \\ Hôpital Pitié-Salpêtrière, 75130 Paris Cédex 13, France; and ${ }^{\S}$ Biologie Moléculaire du Gène, Institut Pasteur, 75724 Paris Cédex 15, France
}

\begin{abstract}
Human chronic myelogenous leukemia (CML) is characterized by a translocation between chromosomes 9 and 22 that results in a BCR-ABL fusion gene coding for chimeric proteins. The junctional region of the $\mathrm{BCR}-\mathrm{ABL}^{\mathrm{b3a} 2}$ molecule represents a potential leukemia-specific antigen which could be recognized by cytotoxic $\mathrm{T}$ lymphocytes (CTL). In fact, we identified a junctional nonapeptide (SSKALQRPV) which binds to HLA-A2.1 molecules. This peptide, as well as those binding to HLA-A3, -A11, and -B8 molecules (previously identified by others), elicits primary CTL responses in vitro from PBLs of both healthy donors and CML patients. Such CTL recognize HLA-matched, BCR-ABL-positive leukemic cells, implying efficient natural processing and presentation of these junctional peptides. Specific CTL were found at high frequency in 5 of 21 CML patients, suggesting that these epitopes are, to some extent, immunogenic in vivo during the course of the disease. These peptides could be useful for the development of specific immunotherapy in CML patients. (J. Clin. Invest. 1998. 101:2290-2296.) Key words: BCR-ABL • cytotoxic T lymphocytes - chromosomal translocation • leukemia $\cdot$ tumor antigen
\end{abstract}

\section{Introduction}

Cytotoxic T lymphocytes (CTL) ${ }^{1}$ are potent effectors of the immune system that could provide long-term antitumor protection if induced by appropriate vaccines. CTL recognize 8-14 amino acid peptides, processed intracellularly and presented by MHC class I molecules (1). Several criteria qualify a peptide, derived from a particular protooncogene product, as a potential immunotherapeutic agent. The peptide needs to bind to MHC class I or class II molecules. Most importantly, the

Address correspondence to Pierre Langlade-Demoyen, Institut Pasteur, Unité d'Immunité Cellulaire Antivirale, 28 rue du Dr. Roux, 75724 Paris, Cédex 15, France. Phone: 33-1-4568-8864; FAX: 33-14568-8942; E-mail: planglad@pasteur.fr

Received for publication 24 April 1997 and accepted in revised form 24 March 1998.

1. Abbreviations used in this paper: a2, abl exon 2; CML, chronic myelogenous leukemia; CTL, cytotoxic T lymphocytes; MuLV, murine leukemia virus; $\mathrm{Ph}^{+}$, Philadelphia chromosome-positive; S9V, SSKALQRPV.

J. Clin. Invest.

(C) The American Society for Clinical Investigation, Inc. 0021-9738/98/05/2290/07 \$2.00

Volume 101, Number 10, May 1998, 2290-2296

http://www.jci.org
MHC/peptide complex should be presented at the surface of cancer cells in sufficient quantity to elicit CTL responses and to render these tumors susceptible to T cell-mediated lysis. Finally, self-tolerance constraints should not preclude the emergence of specific $\mathrm{T}$ cells.

In animal models, both helper $\mathrm{T}$ lymphocytes and CTL participate in the rejection of murine leukemia virus (MuLV)induced tumors $(2,3)$. Furthermore, vaccination with MuLV antigens accelerates tumor rejection in vivo (4). Finally, adoptive transfer of CTL, specifically recognizing MuLV antigens, eradicates disseminated leukemias $(5,6)$. The absence of well characterized human leukemia antigens, selectively expressed by malignant cells and recognizable by $\mathrm{T}$ cells, has prevented the development of immunotherapy.

The rearrangement of the $b c r$ and $a b l$ genes, in Philadelphia chromosome-positive $\left(\mathrm{Ph}^{+}\right)$chronic myelogenous leukemia (CML) and acute lymphoblastic leukemia (7-15), results in the expression of a BCR-ABL fusion protein which represents a leukemia-specific antigen of potential immunotherapeutical interest. In CML, the translocation between chromosomes 9 and 22 (q34, q11) is present in $>95 \%$ of patients (7). In CML, the breakpoint on chromosome 22 is located between either $b c r$ exons b2 and b3 or b3 and b4 (10). Accordingly, after junction with $a b l$ exon 2 (a2), two distinct p210 chimeric BCR-ABL proteins (BCR-ABL ${ }^{\mathrm{b} 2 \mathrm{~A} 2}$ and BCR$\mathrm{ABL}^{\mathrm{b} 3 \mathrm{~A} 2}$ ) are produced, both carrying tyrosine kinase activity (9). In this context, it has been shown that peptides from the joining region of the hybrid molecule $\mathrm{BCR}-\mathrm{ABL}^{\mathrm{b} 3 \mathrm{a} 2}$ (the most frequently observed), induce specific antibodies to BCR-ABL (16), and a CD4 cellular immune response in mice (17) and humans (18). Four different peptides from the junction region have already been identified that bind with either intermediate or high affinity to HLA-A3, -A11, -B8, or both HLA-A3 and -A11 molecules (19-21) and elicit CTL in vitro. However, these studies failed to evidence junction peptide presentation by HLA-A2.1, the most frequent MHC class I allele in the human species, and did not provide evidence of natural CTL responses against these peptides in CML patients.

In this study we examined whether the chimeric BCR$\mathrm{ABL}^{\mathrm{b} 3 \mathrm{a} 2}$ protein serves as a tumor-specific antigen in normal donors and in CML patients. We identified one peptide within the $\mathrm{BCR}-\mathrm{ABL}^{\mathrm{b} 3 \mathrm{a} 2}$ chimeric protein that binds to HLA-A2.1 molecules. We observed that this peptide, as well as the four peptides that have already been described (19-21), elicit in vitro peptide-specific MHC class I-restricted CTL response in HLA-matched healthy donors and CML patients. These peptide-induced CTL lysed HLA-matched BCR-ABL ${ }^{\text {ba } 2}$ positive tumor cells, implying efficient intracellular processing and presentation of the fusion protein. Finally, we have detected CTL that recognize specifically BCR-ABL positive autologous tumors in the peripheral blood of 5 of 21 CML patients, indicating that immunization occurs spontaneously in vivo, at least in some CML patients. 


\section{Methods}

Human cells. PBLs were harvested from buffy coats by centrifugation (600 g, $20 \mathrm{~min}$, room temperature) over a Ficoll-Hypaque solution (Pharmacia, Uppsala, Sweden) and stored in liquid nitrogen. Healthy donors and patients were screened for HLA-A3, -A11, -B8, -A2.1, and p210 BCR-ABL ${ }^{\mathrm{b} 3 \mathrm{a} 2}$ expression. EBV-transformed lymphoblastoid B cell lines were established from PBLs by the standard method.

CML blasts were obtained with informed consent after leukopheresis from patients in myeloid blast crisis. Immunophenotypic analysis of PBMCs showed $\mathrm{CD}_{2}^{+}(<5 \%), \mathrm{CD}^{+}(<5 \%), \mathrm{CD}^{+} 3^{+}$ $(>85 \%), \mathrm{CD} 19^{+}(<5 \%), \mathrm{CD}_{3} 3^{+}(>40 \%)$, and $\mathrm{CD} 34^{+}(>85 \%)$. The CML cells from patients collected by leukopheresis were all $>90 \%$ positive for expression of $\mathrm{CD}_{3} 4^{+}$and $\mathrm{HLA}$ class $\mathrm{I}^{+}$antigens, with side and forward scatter measurements consistent with a blast cell population. Reverse transcriptase PCR using $b c r$ - $a b l$-specific primers were used to confirm the b3a2 translocation. CML tumor cells were cultured in complete RPMI 1640 medium ( $1 \mathrm{mM}$ sodium pyruvate, 100 $\mathrm{U} / \mathrm{ml}$ penicillin, $100 \mu \mathrm{g} / \mathrm{ml}$ streptomycin, and $10 \%$ FCS) supplemented with the following growth factors: GM-CSF $(10 \mathrm{ng} / \mathrm{ml})$, stem cell factor $(80 \mathrm{ng} / \mathrm{ml})$, IL-3 $(20 \mathrm{ng} / \mathrm{ml})$, and erythropoietin $(3 \mathrm{U} / \mathrm{ml})$. $\mathrm{CEM} \times 721.174(\mathrm{~T} 2)$ cells $\left(\mathrm{HLA}-\mathrm{A} 2.1^{+}, \mathrm{TAP} 1 / \mathrm{TAP} 2^{-}\right.$[transporter associated with antigen presentation], and BCR-ABL ${ }^{\mathrm{b3a2}-}$ ) and $\mathrm{K} 562$ cells (HLA class $\mathrm{I}^{-}$, TAP1/TAP2 ${ }^{+}, \mathrm{BCR}^{-} \mathrm{ABL}^{\mathrm{b} 3 \mathrm{a} 2+}$ ) were maintained in RPMI 1640 complete medium.

Peptides and peptide binding assays. HPLC-purified peptides were purchased from Neosystem (Strasbourg, France). BCR-ABL ${ }^{\text {b3a2 }}$ junction peptides are listed (see Table I). HIV1 polymerase peptide (LDTGADDTV) and influenza virus matrix peptide 58-66 (GILGFVFTL) were used as a control. BCR-ABL ${ }^{\mathrm{b} 3 \mathrm{a} 2}$ junction peptide binding capacities were evaluated in inhibition assays using the ${ }^{125}$ I-labeled hepatitis B virus core 18-27 peptide (HBc18-27, FLPSDYFPSV, F10V) as control, and soluble HLA-A2.1 molecules. Thermostabilization assays were performed, using T2 cells grown for $48 \mathrm{~h}$ at $26^{\circ} \mathrm{C}$ in a serum-free medium in the presence of $20 \mathrm{mM}$ peptide. Cells $(3 \times$ $10^{5}$ ) were then shifted to $37^{\circ} \mathrm{C}$ for $3 \mathrm{~h}$ (22). Expression of HLA-A2.1 was measured by flow cytometry using the anti HLA-A, -B, and -C W6.32 mAb on a Becton Dickinson cytofluorometer (San Jose, CA).

Peptide stripping. Cells were pelleted and gently resuspended in $0.5 \mathrm{ml}$ of stripping buffer $\left(0.13 \mathrm{M}\right.$ citric acid, $66 \mathrm{mM} \mathrm{Na}_{2} \mathrm{HPO}_{4}, 150$ $\mathrm{mM} \mathrm{NaCl}$, and $17 \mu \mathrm{g} / \mathrm{ml}$ phenol red). After $30 \mathrm{~s}$, the cell suspension was neutralized by dropwise addition of $0.3 \mathrm{ml}$ of a saturated solution of $\mathrm{Na}_{2} \mathrm{HPO}_{4}$ containing the indicated peptide concentration.

In vitro CTL response induction and ${ }^{51} C r$-release assay. CTL induction was performed as described previously $(23,24)$. Briefly, PBL from HLA-A2.1, -A11, -A3, or -B8 healthy donors or CML patients were incubated with concanavalin A and rIL-2, to induce T lymphoblasts. These lymphoblasts were then peptide-stripped as indicated above and loaded with the desired peptide. These peptide-loaded irradiated lymphoblasts were added to $\mathrm{CD} 8^{+}$-enriched PBLs of the same donor in $\mathrm{T}$ cell culture medium containing rIL-2 $(10 \mathrm{U} / \mathrm{ml})$ and rIL-7 $(30 \mathrm{U} / \mathrm{ml})$. T cells were expanded through weekly restimulation with autologous, peptide-loaded monocytes, rIL-2 $(10 \mathrm{U} / \mathrm{ml})$, and rIL-7 $(30 \mathrm{U} / \mathrm{ml})$. Depending on the frequency of specific CTL precursors, effector cells were expanded for variable periods of time in vitro before specific lytic activity could be detected.

The cell-mediated cytolytic activity in cultures was detected in a 6-h ${ }^{51} \mathrm{Cr}$-release assay. Percent specific lysis of $10,000{ }^{51} \mathrm{Cr}$-labeled target cells in $200 \mu \mathrm{l}$ was determined for various lymphocyte to target cell ratios. Spontaneous ${ }^{51} \mathrm{Cr}$-release values varied between 6 and $20 \%$ of ${ }^{51} \mathrm{Cr}$ incorporated. Cold target inhibition assays were similarly performed. Cold targets (HLA-A2.1, or -B8 transfected, BCR$\mathrm{ABL}^{\mathrm{b} 3 \mathrm{a} 2+} \mathrm{K} 652$ or T2 cells), preloaded $(6 \mathrm{~h}, 100 \mu \mathrm{g} / \mathrm{ml})$ with peptides and washed, were preincubated with effector cells $2 \mathrm{~h}$ before the addition of labeled targets.

Limiting dilution assays. The relative frequencies of $\mathrm{BCR}-\mathrm{ABL}^{\mathrm{b3a}}$ specific CTL were determined by seeding 50-10,000 lymphocytes per well in the presence of in vitro-activated, peptide-loaded, autologous lymphoblasts. After $10 \mathrm{~d}$ of culture, ${ }^{51} \mathrm{Cr}$-labeled, peptide-loaded target cells $\left(10^{4}\right.$ per well) were added in a final volume of $200 \mu \mathrm{l}$. Each dilution was tested in 24 replicated wells. Supernatants were collected after $9 \mathrm{~h}$ of incubation at $37^{\circ} \mathrm{C}$. A well was considered positive if the ${ }^{51} \mathrm{Cr}$-release was $>3 \mathrm{SD}$ above the mean release of control wells containing target cells alone. Effector cell frequencies were estimated by a Poisson distribution analysis (25). Minimal estimates were verified by using the statistical method of $\chi^{2}$ minimization, applying Poisson probability theory to the single hit model (26). For the sake of comparison, CTL frequencies are standardized in the text to the number of CTL per $10^{4}$ lymphocytes.

\section{Results}

A BCR-ABL $L^{b 3 a 2}$ junction peptide binds and stabilizes thermolabile HLA-A2.1 molecules. Seven peptides encoded in the fusion region of $\mathrm{p} 210 \mathrm{BCR}-\mathrm{ABL}^{\mathrm{b} 3 \mathrm{a} 2}$ (Table I) were tested for their capacity to bind to HLA-A $2.1^{+} \mathrm{T} 2$ cells in a previously described thermostabilization assay (22). T2 cells are defective in both TAP1 and TAP2 peptide transporters, resulting in cell surface expression of unstable MHC class I molecules deprived of peptide. Stabilization can be artificially obtained by culturing T2 cells at $26^{\circ} \mathrm{C}$. Fixation of exogenous peptides results in complete stabilization of MHC class I molecules which can be evaluated after incubation at $37^{\circ} \mathrm{C}$. Using this assay, four of seven peptides tested induced a significant stabilization of HLA-A2.1 molecules at the cell surface (Fig. 1). One of them, SSKALQRPV (S9V), exhibited significant binding avidity in a competition assay with the standard HBc 18-27 (F10V) peptide and allowed substantial stabilization of HLA-A2.1 molecules at the surface of T2 cells after $3 \mathrm{~h}$, a delay which should be sufficient for efficient engagement with the T cell receptors (Table II).

Induction of BCR-ABL ${ }^{b 3 a 2}$ junction peptide-specific primary CTL responses from healthy donors. We and others reported previously that primary CTL could be generated in vitro against peptides in mice and humans $(23,24)$. In this study, we used the HLA-A2.1-binding S9V nonapeptide and the four previously identified HLA-A3, -A11, or -B8 binding $\mathrm{BCR}-\mathrm{ABL}^{\mathrm{b} 3 \mathrm{a} 2}$-derived junction peptides to elicit CTL in vitro.

Table I. p210BCR-ABL Peptide Junction Sequences and HLA Class I Binding Capacity

\begin{tabular}{|c|c|c|}
\hline Residues & Sequence & HLA binding capacity \\
\hline 927-934 & SKALQRPV & $-\mathrm{A} 2.1 *$ \\
\hline 926-934 & SSKALQRPV & $-\mathrm{A} 2.1 *$ \\
\hline $925-934$ & QSSKALQRPV & $-\mathrm{A} 2.1 *$ \\
\hline $924-934$ & KQSSKALQRPV & 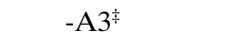 \\
\hline $923-934$ & FKQSSKALQRPV & None* \\
\hline $922-934$ & GFKQSSKALQRPV & None* \\
\hline $921-934$ & TGFKQSSKALQRPV & None* \\
\hline $918-928$ & HSATGFKQSSK & $-\mathrm{A} 3 / \mathrm{A} 22^{\ddagger}$ \\
\hline $920-928$ & ATGFKQSSK & $-\mathrm{A} 11^{\ddagger}$ \\
\hline $922-930$ & GFKQSSKAL & $-\mathrm{B} 8^{\ddagger}$ \\
\hline
\end{tabular}

Residue 928 (K, in bold) corresponds to the fusion codon, residues 918927 being encoded by BCR exon 3 and residues 929-934 by a2 (see reference 10). Binding capacities were either *defined in this study and/or *in reference 20 . 


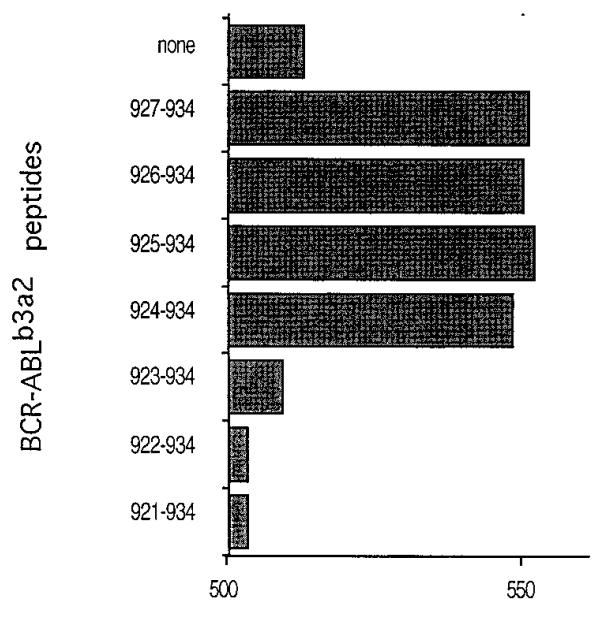

HLA-A2.1 mean fluorescence (A.U.)

Figure 1. Peptide binding to HLA-A2.1. Peptides, listed in Table I, were tested for their capacity to stabilize HLA-A2.1 molecules expressed at the surface of $\mathrm{T} 2$ cells using the $\mathrm{W} 6 / 32 \mathrm{mAb}$ as described in Methods. Mean fluorescence intensity is expressed in arbitrary units (A.U.).

Primary CTL were induced from PBL of HLA-matched healthy donors using peptide-loaded autologous lymphoblasts as stimulator cells. Assaying these in vitro stimulated lymphocytes against peptide-pulsed, HLA-matched, EBV-transformed target cells, specific lysis was obtained in three of five HLA-A11, in two of five HLA-A3, in two of four HLA-B8, and in two of six HLA-A2.1 donors. These CTL are specific for BCR-ABL since they do not recognize HLA-matched, EBV-transformed target cells pulsed with the irrelevant HIV1 polymerase and influenza peptide (Table III, row 2) (Fig. 2a). These CTL have classical CD8 ${ }^{+}$phenotypes (data not shown) and, as illustrated in Fig. $2 a$ and $b$, BCR-ABL ${ }^{\mathrm{b} 3 \mathrm{a} 2}$ peptide-specific CTL lines are restricted since only HLA-matched A2.1
Table II. Binding Competition Assay

\begin{tabular}{lrc}
\hline \multicolumn{1}{c}{ Residues } & \multicolumn{1}{c}{ Sequence } & Inhibition \\
\hline & & $\%$ \\
926-934 (S9V) & S SKALQRPV & 31 \\
923-934 (F12V) & FKQS SKALQRPV & 0 \\
922-934 (G13V) & GFKQS SKALQRPV & 0 \\
921-934 (T14V) & TGFKQS SKALQRPV & 0 \\
F10V & FLPSDYFPSV & 94 \\
& & \\
\hline
\end{tabular}

The ability of BCR-ABL ${ }^{\mathrm{b} 3 \mathrm{a} 2}$ peptides to bind soluble HLA-A2.1 molecules was evaluated in a competition assay using ${ }^{125}$ I HBc $18-27$ (F10V) as a standard peptide. Results are expressed in percent inhibition at a $20 \mathrm{mM}$ final concentration of the competitor peptide.

and B8, transfected-K562 cells are lysed. Having established the capacity of the five synthetic junction peptides to stimulate in vitro primary CTL responses, we next evaluated whether these CTL lines could also recognize HLA-matched CML cells or HLA-transfected K562 tumor cells expressing the BCR$\mathrm{ABL}^{\mathrm{b} 3 \mathrm{a} 2}$ chimeric protein endogenously.

As indicated in Table III (rows 3 and 4) and Fig. 2, specific lysis of HLA-matched, BCR-ABL ${ }^{\mathrm{b} 3 \mathrm{a} 2}$-positive tumor cells was observed in five of the seven tested CTL lines. More interestingly, specific recognition of HLA-matched tumor cells, endogenously expressing the BCR-ABL ${ }^{\mathrm{b} 3 \mathrm{a} 2}$ chimeric molecules, was observed, whichever the tested class I restricting molecule (Fig. 2, $a$ and $b$ ) (Table III). Therefore, the BCR-ABL ${ }^{\mathrm{b} 3 \mathrm{a} 2}$ molecule is effectively intracellularly processed and natural peptides, similar to the synthetic ones, are presented by the corresponding HLA class I molecules on the cell surface. Some CTL lines (usually of lower lytic capacity) failed to recognize the tumor target cells, suggesting either limited cell surface presentation of the junction peptides or low TcR affinity.

In vitro induction of $B C R-A B L^{b 3 a 2}$ junction peptide-specific $C T L$ responses in $C M L$ patients. Having established that BCR$\mathrm{ABL}$ junction peptides can induce in vitro CTL responses from the PBL of healthy donors, and that identical peptides

Table III. Primary CTL In Vitro Responses of Healthy Donors

\begin{tabular}{|c|c|c|c|c|c|c|c|c|c|c|c|c|c|c|c|c|c|c|}
\hline \multirow[b]{3}{*}{ Target cells } & \multicolumn{18}{|c|}{ Donors } \\
\hline & \multicolumn{4}{|c|}{ HLA-A3 } & \multicolumn{6}{|c|}{ HLA-A11 } & \multicolumn{4}{|c|}{ HLA-A2.1 } & \multicolumn{4}{|c|}{ HLA-B8 } \\
\hline & \multicolumn{2}{|c|}{ DO1 } & \multicolumn{2}{|c|}{ DO5 } & \multicolumn{2}{|c|}{ DO1 } & \multicolumn{2}{|c|}{ DO3 } & \multicolumn{2}{|c|}{ DO5 } & \multicolumn{2}{|c|}{ DO1 } & \multicolumn{2}{|c|}{$\mathrm{DO} 2$} & \multicolumn{2}{|c|}{ DO1 } & \multicolumn{2}{|c|}{ DO4 } \\
\hline $\mathrm{E} / \mathrm{T}$ & $30: 1$ & $10: 1$ & $30: 1$ & $10: 1$ & $30: 1$ & $10: 1$ & $30: 1$ & $10: 1$ & $30: 1$ & $10: 1$ & $30: 1$ & 10:1 & $30: 1$ & $10: 1$ & $30: 1$ & $10: 1$ & $30: 1$ & $10: 1$ \\
\hline $\begin{array}{l}\text { HLA-matched EBV cells } \\
\text { with BCR-ABL peptide }\end{array}$ & 65 & 20 & 35 & 15 & 40 & 20 & 35 & 22 & 68 & 35 & 60 & 38 & 25 & 15 & 30 & 15 & 50 & 32 \\
\hline $\begin{array}{l}\text { HLA-matched } \\
\text { cells with HIV peptide }\end{array}$ & 15 & 8 & 10 & 3 & 18 & 5 & 15 & 7 & 20 & 9 & 10 & 12 & 8 & 7 & 8 & 5 & 20 & 8 \\
\hline $\begin{array}{l}\text { HLA-matched tumor cell } \\
\text { HLA-mismatched }\end{array}$ & 45 & 18 & 4 & 3 & ND & ND & ND & ND & 55 & 45 & 40 & 32 & 25 & 8 & 3 & 0 & 35 & 22 \\
\hline tumor cell & 12 & 3 & 5 & 2 & ND & ND & ND & ND & 22 & 8 & 12 & 8 & 3 & 2 & 3 & 1 & 8 & 3 \\
\hline
\end{tabular}

CTL lines, derived by in vitro stimulation of PBL from healthy donors with autologous T cell blasts pulsed with BCR-ABL ${ }^{\text {3a2 }}$ junction peptides were tested against EBV-transformed autologous target cells pulsed either with the relevant BCR-ABL ${ }^{\text {b3a2 }}$ junction peptide (row 1), or the irrelevant HIV polymerase peptide (row 2). These CTL lines were similarly tested against autologous (row 3 ) and HLA-mismatched, BCR-ABL ${ }^{\text {b3a2 }}$-positive CML leukemic cells (row 4). Percentages of specific killing are given for two effector-to-target ratios $(30: 1,10: 1)$. $N D$, not determined. 


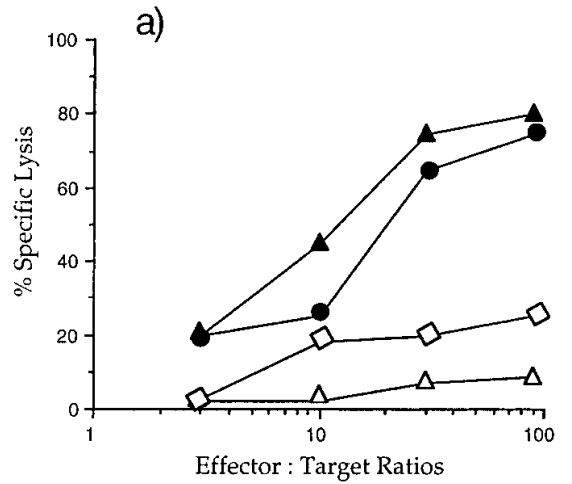

were naturally produced in $\mathrm{BCR}-\mathrm{ABL}^{\mathrm{b3a2}}$-positive cells, we next tested whether similar responses could be induced from the PBL of CML patients. Autologous, peptide-loaded blast cells or patients' dendritic cells, which express the chimeric protein, were used as stimulators. Using this approach, specific CTL could be in vitro-stimulated from PBL of 2 of 4 HLA-A3, 2 of 7 HLA-B8, and 3 of 10 HLA-A2.1 CML patients (Table IV). Lysis was observed with peptide-pulsed autologous EBVtransformed cells (Table IV, row 1) and, for four of seven CTL lines, with autologous CML cells endogenously expressing the BCR-ABL ${ }^{\text {baa2 }}$ molecules. Specificity of lysis was assessed by testing both autologous, EBV-transformed cells pulsed with the HIV-1 polymerase peptide (Table IV, row 2) and HLAmismatched BCR-ABL ${ }^{\text {b3a2 }}$-positive CML cells. Specificity of lysis was further verified in cold target inhibition assays. Testing HLA-A2.1-restricted, BCR-ABL ${ }^{\mathrm{b3} 2}-$ specific CTL, and ${ }^{51} \mathrm{Cr}$-labeled autologous tumor cells, cold target inhibition of lysis was observed with T2 cells loaded with the S9V BCRABL but not with a control influenza peptide (Fig. $3 c$ ), and with BCR-ABL ${ }^{\text {b3a2 }}$ positive K562 cells expressing HLA-A2.1
Figure 2. MHC restriction and MHC specificity of BCR-ABLreactive CTL. (a) Specific CLT from an HLA-A2.1 CML1 patient were tested on HLA-A2.1 ${ }^{+}$T2 cells pulsed with the BCR-ABL 926-934 (closed triangles) or the influenza virus matrix 58-66 peptide (open triangles). These CTL were similarly tested against HLA-A2.1untransfected (open diamonds) or HLA-A2.1 ${ }^{+}$-transfected (closed circles) BCR-ABL ${ }^{\mathrm{b} 3 \mathrm{a} 2+} \mathrm{K} 562$ cells. $(b)$ CTL from an HLA-B8 ${ }^{+}$CML patient tested against HLA-B8 ${ }^{-}-$ untransfected (open diamonds), HLA-A2. $1^{+}$-transfected (closed circles), or HLA-B8 ${ }^{+}$-transfected (open circles) BCR-ABL ${ }^{\mathrm{b} 32+} \mathrm{K} 562$ cells.

Effector : Target Ratios

molecules (Fig. $3 b$ ) but not with K562 cells expressing HLA$\mathrm{B} 8$ molecules and the CML-B8 ${ }^{+}$cells (Fig. 3 b). A reverse pattern of inhibition was observed, assaying HLA-B8-restricted, BCR-ABL-specific CTL and HLA-B8-, HLA-A2.1-transfected $\mathrm{K} 562$ cells, or CML-A2 ${ }^{+}$cells (Fig. 3 a). Together, these results indicate that $\mathrm{BCR}-\mathrm{ABL}-$ specific $\mathrm{CTL}$ responses can be stimulated in vitro using patients' PBL and autologous, peptide-loaded cells. They further confirm that endogenous processing of $\mathrm{BCR}-\mathrm{ABL}^{\mathrm{b3a2}}$ molecules results in cell surface presentation, by HLA-A2.1, -A3, and -B8 molecules, of antigenic junctional peptides similar to those defined by the binding and stabilization experiments. Since these peptides are presented on the surface of the leukemic cells, we next questioned whether these cells could be immunogenic in vivo.

Specific BCR-ABL CTL detected in vivo in 5 of $21 C M L$ patients. Limiting dilution analysis was performed to determine the frequency of specific CTL in PBL of CML patients. High frequencies of BCR-ABL ${ }^{\mathrm{b} 322}$-specific $\mathrm{CTL}$ were found in 5 of 21 CML patients compared to healthy donors (Table V). In contrast, no meaningful differences in influenza virus-spe-

Table IV. BCR-ABL ${ }^{\text {b3a2 }}$-specific CTL In Vitro Responses of CML Patients

\begin{tabular}{|c|c|c|c|c|c|c|c|c|c|c|c|c|c|c|}
\hline \multirow[b]{3}{*}{ Targets } & \multicolumn{14}{|c|}{ Patients } \\
\hline & \multicolumn{4}{|c|}{ HLA-A3 } & \multicolumn{6}{|c|}{ HLA-A2.1 } & \multicolumn{4}{|c|}{ HLA-B8 } \\
\hline & \multicolumn{2}{|c|}{ CML2 } & \multicolumn{2}{|c|}{ CML4 } & \multicolumn{2}{|c|}{ CML1 } & \multicolumn{2}{|c|}{ CML5 } & \multicolumn{2}{|c|}{ CML10 } & \multicolumn{2}{|c|}{ CML1 } & \multicolumn{2}{|c|}{ CML2 } \\
\hline $\mathrm{E} / \mathrm{T}$ & $30: 1$ & $10: 1$ & $30: 1$ & $10: 1$ & $30: 1$ & $10: 1$ & $30: 1$ & $10: 1$ & $30: 1$ & $10: 1$ & $30: 1$ & $10: 1$ & $30: 1$ & $10: 1$ \\
\hline $\begin{array}{l}\text { HLA-matched EBV cells } \\
\text { with BCR-ABL peptide }\end{array}$ & 75 & 45 & 45 & 25 & 35 & 15 & 25 & 15 & 38 & 25 & 48 & 30 & 50 & 25 \\
\hline $\begin{array}{l}\text { HLA-matched EBV cells } \\
\text { with HIV peptide }\end{array}$ & 25 & 10 & 8 & 3 & 10 & 3 & 12 & 8 & 15 & 7 & 12 & 7 & 15 & 5 \\
\hline Autologous tumor cells & 50 & 25 & 9 & 6 & 25 & 15 & 30 & 22 & 8 & 3 & 35 & 28 & 7 & 6 \\
\hline HLA-mismatched tumor cells & 10 & 8 & 8 & 5 & 5 & 4 & 6 & 8 & 5 & 2 & 7 & 6 & 4 & 5 \\
\hline
\end{tabular}

PBL from CML patients were stimulated in vitro four times with autologous $\mathrm{T}$ cell blasts pulsed with BCR-ABL ${ }^{\mathrm{b} 3 \mathrm{a} 2}$ junction peptides. CTL lines were tested against EBV-transformed autologous target cells pulsed with either the relevant BCR-ABL ${ }^{\text {b3a2 }}$ junction peptides listed (Table I, row 1) or the irrelevant HIV polymerase peptide (row 2). CTL lines were similarly assayed against autologous (row 3) and HLA-mismatched (BCR-ABL ${ }^{\text {b322 }}$-positive) CML leukemic target cells (row 5). Percentages of specific killing are given for two effector-to-target ratios (30:1, 10:1). 

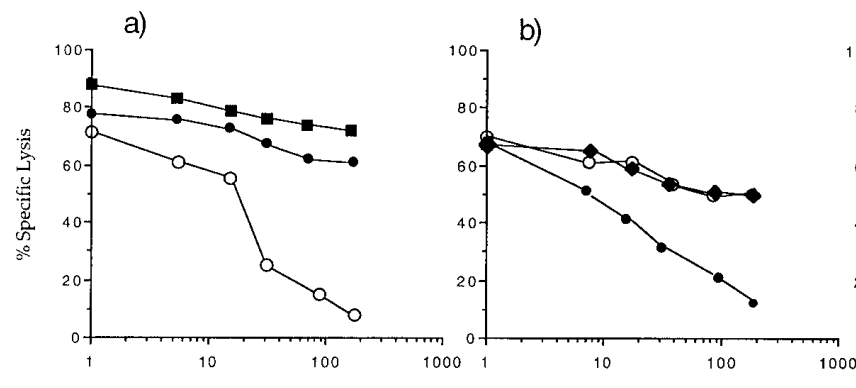

Cold : Hot Target Ratios
Figure 3. Cold target inhibition of BCR-ABL-specific CTL. BCR-ABL-specific CTL lines from HLA-B8 $(a)$ and HLA-A2.1 ( $b$ and c) CML patients were assayed against autologous CML tumor cells. In the absence of cold targets, an $80 \%$-specific lysis was observed at a 20:1 ET ratio. Lysis was similarly evaluated in the presence of BCR-ABL ${ }^{\mathrm{b} 3 \mathrm{a} 2+}$ HLA-B8 (open circles) or HLA-A2.1 (closed circles) transfected K562, HLA-B8 (closed diamonds) or HLA-A2 (closed squares) autologous CML, and influenza virus matrix 58-66 (closed triangles) or BCR-ABL 926-934 (open triangles) peptide-pulsed T2 cold target cells. cific CTL frequencies were detected between the CML patients and the healthy donors. These specific CTL were detected using peptide-pulsed syngeneic EBV-transformed cells. To eliminate a potential autoreactivity and to evaluate the in vivo potential of BCR-ABL-specific CTL, limiting dilution assays were performed using either autologous CML, autologous

Table V. BCR-ABL-specific CTLp Frequencies in CML Patients and Healthy Donors

\begin{tabular}{|c|c|c|c|c|c|}
\hline \multicolumn{3}{|c|}{ CML patients } & \multirow[b]{2}{*}{ HLA } & \multicolumn{2}{|c|}{ Healthy donors } \\
\hline & BCR-ABL & Influenza & & BCR-ABL & Influenza \\
\hline 1 & 0.02 & 0.5 & $-\mathrm{A} 2.1$ & 0.1 & 1.2 \\
\hline 2 & 0.07 & 0.6 & $-\mathrm{A} 2.1$ & 0.09 & 0.9 \\
\hline 3 & UN & 0.21 & $-\mathrm{A} 2.1$ & 0.06 & 0.1 \\
\hline 4 & 0.09 & 0.9 & $-\mathrm{A} 2.1$ & 0.04 & 1.3 \\
\hline 5 & 0.05 & 0.5 & $-\mathrm{A} 2.1$ & 0.08 & 1.6 \\
\hline 6 & UN & 0.9 & -A2.1 & 0.15 & 1.1 \\
\hline 7 & 0.07 & 0.6 & $-\mathrm{A} 2.1$ & 0.9 & 1.2 \\
\hline 8 & 15 & 1 & $-\mathrm{A} 2.1$ & 0.06 & 1.5 \\
\hline 9 & 13 & 1 & $-\mathrm{A} 2.1$ & 0.9 & 1.2 \\
\hline 10 & 20 & 1.2 & $-B 8$ & 0.08 & 1.5 \\
\hline 11 & 0.02 & 0.5 & $-B 8$ & 0.01 & 0.2 \\
\hline 12 & 0.07 & 0.6 & $-\mathrm{B} 8$ & UN & 0.9 \\
\hline 13 & UN & 0.21 & $-\mathrm{A} 3$ & 0.06 & 0.81 \\
\hline 14 & 0.09 & 0.9 & $-\mathrm{A} 3$ & UN & 0.3 \\
\hline 15 & 5 & 0.5 & $-\mathrm{A} 3$ & 0.01 & 0.6 \\
\hline 16 & UN & 0.9 & $-\mathrm{A} 3$ & 0.01 & 1.1 \\
\hline 17 & 0.07 & 0.6 & $-\mathrm{A} 3$ & UN & $\mathrm{UN}$ \\
\hline 18 & UN & 1 & $-\mathrm{A} 3$ & 0.03 & 2 \\
\hline 19 & 1 & 1 & -A11 & 0.09 & 1 \\
\hline 20 & 8 & 1.2 & $-\mathrm{A} 11$ & UN & 1.1 \\
\hline
\end{tabular}

BCR-ABL and influenza-specific CTL were generated from $20 \mathrm{CML}$ patients and 20 healthy donors in microcultures under limiting dilution conditions and tested in a 9-h assay against ${ }^{51} \mathrm{Cr}$-labeled syngeneic EBVtransformed cells pulsed with the relevant BCR-ABL junction or influenza peptide. CTL frequencies per $10^{4}$ lymphocytes were estimated after $10 \mathrm{~d}$ in culture. $U N$, undetectable.
EBV, or autologous normal B cells as target cells. These last two cells were tested and found negative for the expression of BCR-ABL. A higher CTL frequency was found on the autologous CML cells compared to autologous EBV-transformed cells or normal B cells (Table VI). This result indicates that some CML patients spontaneously generated CTL responses against the $\mathrm{BCR}-\mathrm{ABL}^{\mathrm{b} 3 \mathrm{a} 2}$ translocation product.

\section{Discussion}

This study identifies, for the first time, an HLA-A2.1-restricted peptide from the $\mathrm{BCR}-\mathrm{ABL}^{\mathrm{b} 3 \mathrm{a} 2}$ junctional region which $(a)$ binds to HLA-A2.1 molecules, $(b)$ stimulates in vitro-specific CTL responses using PBL from both healthy donors and CML patients, and $(c)$ is spontaneously processed and presented at the surface of CML cells. Such presentation results, for certain patients, in a sizable expansion of CML-specific CTL. Similar parallel studies with other BCR-ABL ${ }^{\mathrm{b} 3 \mathrm{a} 2}$ junction peptides presented by other MHC class I alleles led to the same observations. Considering the large representation of these HLA class I alleles (for example, HLA-A2.1 is found in $40 \%$ of individuals), these results might be of general immunotherapeutic interest.

Using a similar approach, other groups searched for BCR$\mathrm{ABL}^{\mathrm{b} 3 \mathrm{a} 2}$-derived peptides and failed to find any strong binder to HLA-A2.1 molecules (18-21). This is probably due to the fact that the peptide identified in this study does not exhibit the consensus HLA-A2.1 binding motif. It should be further pointed out that the binding and thermostabilization assay of HLA molecules which we used, at $26^{\circ} \mathrm{C}$ in serum-free medium, is very sensitive. Thus, as noted by others, a search for antigenic peptides should not be limited to peptides displaying canonical motifs (27), since secondary anchor residues can compensate for the absence of the major ones. Additionally, some low affinity peptides have been proved immunogenic when help is provided and if presentation is insured by appropriate antigen-presenting cells (28). One should also note that a small number of specific MHC/peptide complexes on target cells is sufficient for recognition by activated T cells $(29,30)$.

Certain BCR-ABL ${ }^{\mathrm{b} 3 \mathrm{a} 2}$-specific, in vitro-induced $\mathrm{CD}^{+}$ CTL lines from different individuals were able to lyse either 


\begin{tabular}{|c|c|c|c|c|c|}
\hline \multirow[b]{2}{*}{ Target cells } & \multicolumn{5}{|c|}{ CML patients } \\
\hline & 8-HLA-A2.1 & 9-HLA-A2.1 & 10-HLA-B8 & 19-HLA-A3 & 20-HLA-A11 \\
\hline $\mathrm{CML}$ autologous tumor $\left(\mathrm{BCR}-\mathrm{ABL}^{+}\right)$ & 10 & 15 & 30 & 0.5 & 5 \\
\hline Autologous EBV-transformed cells (BCR-ABL ${ }^{-}$) & 0.01 & 0.02 & 0.03 & 0.05 & 0.05 \\
\hline Autologous normal B cells (BCR-ABL $\left.{ }^{-}\right)$ & 1 & 2 & 1 & 0.09 & 0.1 \\
\hline
\end{tabular}

BCR-ABL-specific CTL were generated in microcultures under limiting dilution conditions and tested against ${ }^{51} \mathrm{Cr}-\mathrm{labeled} \mathrm{BCR}^{-\mathrm{ABL}}{ }^{\mathrm{b3a} 2+} \mathrm{CML}$ autologous tumor (row 1), BCR-ABL ${ }^{\mathrm{b3a2}-}$ autologous EBV-transformed (row 2), and autologous normal B cells (row 3 ).

HLA-matched, transfected K562 (BCR-ABL ${ }^{\mathrm{b} 3 \mathrm{a} 2}$ positive), or autologous CML leukemic cells. This indicates that the p210 BCR-ABL ${ }^{\mathrm{b} 3 \mathrm{a} 2}$ fusion molecules can be processed by tumor cells with efficient surface antigenic peptide presentation by either HLA-A3, -A11, -A2.1 or -B8 class I molecules. However, in $\sim 75 \%$ of cases, we failed to elicit, in healthy donors as well as in CML patients, in vitro-sizable CTL responses, even when tested with peptide-pulsed, EBV-transformed sensitive target cells. Additionally, we observed frequently less efficient lysis of $\mathrm{BCR}-\mathrm{ABL}^{\mathrm{b} 3 \mathrm{a} 2}$ tumor cells (which only present peptides endogenously processed). Many reasons might explain such observations. BCR-ABL-processed peptides might be expressed in relatively low amount on cell surfaces. In vitro induction of CTL from a few million $\mathrm{T}$ lymphocytes might often result in the stimulation of $\mathrm{CD}^{+} \mathrm{T}$ lymphocytes of lower affinity than responses developing in vivo, assuming high affinity clones to be of low frequencies. Finally, it is possible, as often documented, that in patients, specific CTL clones could be anergized, even deleted leukemic cells lacking some essential costimulatory molecules or secreting inhibitory cytokines (31, 32). However, there are ways to circumvent these difficulties. The amount of HLA class I antigenic peptide complexes required for target cell recognition is lower than the amount required for CTL induction. Loading exogenously dendritic cells with synthetic peptides or transfecting them with potent expressing vectors, limited to the $\mathrm{BCR}-\mathrm{ABL}^{\mathrm{b} 3 \mathrm{a} 2}$ junction region, should improve the CML patient leukemia-specific CTL responses. Successes with the later approach have been reported recently in animal experimental systems, even at advanced stages of tumor development. In this line of thinking, one should stress that the BCR-ABL ${ }^{\mathrm{b} 3 \mathrm{a} 2}$ junction peptides are not self, minimizing the risk of autoimmunity. Significantly, circulating CTL in patients show no detectable toxicity in vivo towards normal tissues. However, this does not exclude the possibility, since the BCR-ABL protein is overexpressed in CML, that other CML-specific T cells directed against cryptic or subdominant BCR or ABL peptides could also be stimulated in the respect of normal cells, as established in certain mouse studies $(33,34)$.

Although a larger number of patients needs to be evaluated to reach a general conclusion, this study establishes that BCR-ABL-specific CTL exist at a high frequency in 25\% of the leukemic patients, therefore, suggesting an active specific immune surveillance against CML. Thus, one might hope that the stimulation or reactivation of such responses in patients undergoing monoclonal expansion during the acute late phase of CML could have a significant therapeutical interest.

It is likely that the BCR-ABL protein is present in the ear- liest pluripotent malignant progenitor undergoing monoclonal expansion in CML patients (35-37). Only rarely do $\mathrm{Ph} 1^{+} \mathrm{CML}$ become $\mathrm{Ph} 1^{-}$, and only rarely do $\mathrm{Ph} 1^{+} \mathrm{CML}$ lose detectable BCR-ABL fusion transcripts during disease progression (38). Since the BCR-ABL protein is intimately associated with transformation (35), antigen-negative variants, which might result from immunization, should not have a malignant phenotype. In view of our results, adoptive $\mathrm{T}$ cell immunotherapy and peptide-based vaccination are both conceivable in patients with CML.

\section{Acknowledgments}

We thank M.-P. Schutze for critically reviewing the manuscript.

This work was funded by the Institut Pasteur. P. Yotnda is the recipient of a fellowship from the Ligue Nationale contre le Cancer and the Association pour la Recherche contre le Cancer. This work was further supported by grants from the Association pour la Recherche contre le Cancer (ARC) and the Ligue Nationale contre le Cancer.

\section{References}

1. Townsend, A., and H. Bodmer. 1989. Antigen recognition by class I-restricted T lymphocytes. Ann. Rev. Immunol. 7:601-624.

2. Greenberg, P.D., M.A. Cheever, and A. Feffer. 1981. Eradication of disseminated murine leukemia by chemoimmunotherapy with cyclophosphamide and adoptive transfer. J. Exp. Med. 154:952-963.

3. Leclerc, J.C., and H. Cantor. 1980. T cell-mediated immunity to oncornavirus induced tumors. II. Ability of different T cell subsets to prevent tumor growth in vivo. J. Immunol. 124:851-854.

4. Plata, F., P. Langlade-Demoyen, J.-P. Abastado, T. Berbar, and P. Kourilsky. 1987. Retrovirus antigens recognized by cytolytic T lymphocytes activate tumor rejection in vivo. Cell. 48:231-240.

5. Cheever, M.A., D.B. Thompson, J.P. Kharnet, and P.D. Greenberg. 1986. Antigen-driven long-term cultured T cells proliferate in vivo, distribute widely, mediate specific tumor therapy, and persist long-term as functional memory T cells. J. Exp. Med. 163:1100-1112.

6. Greenberg, P.D., D.E. Kern, and M.A. Cheever. 1985. Therapy of disseminated murine leukemia with cyclophosphamide and immune Lyt-1+ T cells: tumor eradication does not require participation of cytotoxic T cells. $J$. Exp. Med. 161:1122-1134.

7. Bloomfeld, C.D., Z.D. Rowley, A.I. Goldman, S.D. Lawler, J. Secker, L.M. Walker, and F. Mitelman. 1982. Third international workshop on chromosomes in leukemia. Cancer Res. 43:868a (Abstr.)

8. Gale, R.P., and E. Canaani. 1984. An 8-kilobase abl RNA transcript in chronic myelogenous leukemia. Proc. Natl. Acad. Sci. USA. 81:5648-5652.

9. Konopka, J.P., S.M. Watanabe, and O.N. Witte. 1984. An alteration of human c-abl protein in the K562 leukemia cells unmasks associated tyrosine kinase activity. Cell. 37:1035-1042.

10. Shtivelman, E., B. Lifshitz, R.P. Gale, and E. Canaani. 1985. Fused transcript of abl and bcr genes in chronic myelogenous leukemia. Nature. 315:550-554

11. Stam, K., N. Heisterkamp, F.H. Reynolds, Jr., and J. Groffen. 1987. Evidence that the phl gene encodes a 160,000-dalton phosphoprotein. Mol. Cell. Biol. 7:1955-1960.

12. Kloetzer, W., R. Kurzrock, L. Smith, M. Talpas, M. Spiller, R.B. Arlinghaus, and J.U. Gutterman. 1995. The human cellular abl gene product in the chronic myelogenous leukemia cell line K562 has an associated tyrosine protein 
kinase activity. Virology. 140:230-238.

13. Ben Neriak, Y., G.Q. Daley, A.M. Mes-Masson, O.N. Witte, and D. Baltimore. 1986. The chronic myelogenous leukemia-specific p210 protein is the product of the bcr/abl hybrid gene. Science. 233:212-214.

14. Kurzrock, R., W.S. Kloetzer, M. Talpas, M. Block, R. Walterzs, R.B. Arlinghaus, and J.U. Gutterman. 1987. Identification of molecular variants of p210 brr-abl in chronic myelogenous leukemia. Blood. 70:233-236.

15. Canaani, E., C. Marcelle, and E. Fainstein. 1991. BCR-ABL RNA in chronic myelogenous leukemia and acute lymphoblastic leukemia. In Chronic Myelogenous Leukemia: Molecular Approaches to Research and Therapy. Vol. 13. A. Deisserath and R.B. Arlinghaus, editors. Dekker, New York. 217240 .

16. van Denderen, Y., A. Hermans, T. Meenwsen, C. Troelstra, N. Zegers, W. Boersma, G. Grosfeld, and W. van Ewijk. 1989. Antibody recognition of the tumor-specific bcr-abl joining region in chronic myeloid leukemia. J. Exp. Med. 169:87-98.

17. Chen, W., D.J. Peace, D.K. Rovira, S.G. You, and M.A. Cheever. 1992. T-cell immunity to the joining region of p210 BCR-ABL protein. Proc. Natl. Acad. Sci. USA. 89:1468-1472.

18. Ben Bosch, G.J.A., A.C. Toornvliet, T. Friede, C.J.M. Melief, and O.C. Leeksma. 1995. Recognition of peptides corresponding to the joining region of p210 BCR-ABL protein by human T cells. Leukemia. 9:1344-1348.

19. Cullis, J.O., A.J. Barret, J.M. Goldman, and R.I. Lechler. 1994. Binding of BCR-ABL junctional peptides to major histocompatibility complex (MHC) class I molecules: studies in antigen-processing defective cell lines. Leukemia. 8: $165-170$

20. Bocchia, M., P.A. Wentworth, S. Southwood, J. Sidney, K. McGraw, D.A. Scheinberg, and A. Sette. 1995. Specific binding of leukemia oncogene fusion protein peptides to HLA class I molecules. Blood. 85:2680-2684.

21. Bocchia, M., T. Korontsvit, Q. Xu, S. Mackinnon, S.Y. Yang, A. Sette, and D.A. Scheinberg. 1996. Specific human cellular immunity to bcr-abl oncogene-derived peptides. Blood. 87:3587-3592.

22. Ljunggren, H.G., N.J. Stam, C. Ohlen, J.J. Neefjes, P. Höglund, M.T. Heemels, J. Bastin, T.N. Schumacher, A. Townsend, K. Kärre, et al. 1990. Empty MHC class I molecules come out in the cold. Nature. 346:476-480.

23. Langlade-Demoyen, P., J.-P. Levraud, P. Kourilsky, and J.-P. Abastado. 1994. Primary cytotoxic T lymphocyte induction using peptide-stripped autologous cells. Int. Immunol. 6:1759-1766.

24. Celis, E.V., C. Tsai, R. Crimi, P.A. DeMars, R.W. Wentworth, H.M. Chesnut, A. Grey, A. Sette, and H.M. Serra. 1994. Induction of anti-tumor cytotoxic T lymphocytes in normal humans using primary cultures and synthetic epitopes. Proc. Natl. Acad. Sci. USA. 91:2105-2109.
25. Lefkovits, I., and H. Waldmann. 1979. Limiting Dilution Analysis of Cells in the Immune System. Cambridge University Press, New York. 262 pp.

26. Taswell, C. 1981. Limiting dilution assays for the determination of immunocompetent cell frequencies. I. Data analysis. J. Immunol. 126:1614-1620.

27. Rammensee, H.G., T. Friede, and S. Stevanovic. 1995. MHC ligands and peptide motifs: first listing. Immunogenetics. 41:178-228.

28. Heath, W.R., L. Kuer-Nielsen, and M.W. Hoffman. 1993. Avidity for antigen can influence the helper dependence of $\mathrm{CD}^{+} \mathrm{T}$ lymphocytes. J. Immunol. 151:5993-6001.

29. Harding, C.V., and E.R. Unanue. 1990. Quantitation of antigen presenting cell MHC class II/peptide complexes necessary for T-cell stimulation. $\mathrm{Na}$ ture. 346:574-576.

30. Christnick, E.R., M.A. Luscher, B.H. Barber, and D.B. Williams. 1991. Peptide binding to class I MHC on living cells and quantitation of complexes required for CTL lysis. Nature. 352:67-70.

31. Schwartz, R.H. 1989. Acquisition of immunologic self-tolerance. Cell. 57:1073-1081

32. Webb, S., C. Morris, and J. Sprent. 1990. Extrathymic tolerance of mature T cells: clonal elimination as a consequence of immunity. Cell. 63:12451256.

33. Cibotti, R., J.M. Kanellopoulos, J.P. Cabaniols, O. Halle-Panenko, K Kosmatopoulos, E. Sercarz, and P. Kourilsky. 1992. Tolerance to a self-protein involves its immunodominant but not subdominant peptides. Proc. Natl. Acad. Sci. USA. 89:416-420.

34. Cibotti, R., J.-P. Cabaniols, C. Pannetier, C. Dalarbre, I. Vergnon, J.M. Kanellopoulos, and P. Kourilsky. 1994. Public and private V beta T cell receptor repertoires against hen egg white lysozyme (HEL) in nontransgenic versus HEL transgenic mice. J. Exp. Med. 180:861-872.

35. Fialkow, P.J., R.J. Jacobson, and T. Papayannopoulu. 1977. Chronic myelocytic leukemia: clonal origin in a stem cell common to the granulocyte erythrocyte platelet and monocyte/macrophage. Am. J. Med. 63:125-130.

36. Szczylik, C., T. Skorski, N.C. Nicolaides, L. Manzella, L. Malaguarnera, D. Venturelli, A.M. Gewirtz, and B. Calabretta. 1991. Selective inhibition of leukemia cell proliferation by BCR-ABL antisense oligonucleotides. Science. 253:562-565.

37. Lisker, R., L. Casas, O. Mutchwick, F. Perez-Chavez, and J. Labardini. 1980. Late-appearing Philadelphia chromosome in two patients with chronic myelogenous leukemia. Blood. 56:812-814.

38. Bartram, C.R., J.W. Janssen, R. Becher, A. de Klein, and G. Grosveld. 1986. Persistence of chronic myelocytic leukemia despite deletion of rearranged bcr/c-abl sequences in blast crisis. J. Exp. Med. 164:1398-1404. 